\title{
Diversity, activity analysis and effectivity of rhizobacteria in plants rhizosphere on the growth of Arachis hypogaea $\mathrm{L}$ plants
}

\author{
Sri Purwaningsih* \\ Research Center for Biology, Indonesian Institute of Sciences, Indonesia.
}

\begin{abstract}
This research was conducted to observe the diversity, activity analysis and effectivity of rhizobacteria in plant rhizosphere on the growth of Arachis hypogaea L plants. The soil samples were collected from rhizosphere soil from different plants at Suro Muncang village and Bukit Peninjauan village. The rhizobacteria was isolated in YEMA media to test the qualitative activity including nitrogen, indole acetic acid (IAA) fixation, and siderophores. An isolate used in this research were $1 \mathrm{RB}, 2 \mathrm{RB}, 8 \mathrm{RB}, 9 \mathrm{RB}, 10 \mathrm{RB}, 11 \mathrm{RB}, 16 \mathrm{RB}, 17 \mathrm{RB}, 19 \mathrm{RB}, 20 \mathrm{RB}, 21 \mathrm{RB}$. Experimental plants were harvested after 45 days. The parameters used were the dry weight of shoots, roots, nodules root, total plants, number of nodules, and symbiotic capacity. The research design was conducted by Completely Randomized Design with three replications per treatment. The results showed that the population of rhizobacteria ranged between 13-51 x $10^{5} \mathrm{CFU} / \mathrm{g}$ soil. Rhizobacterial isolates showed different level of plant growth promotion, which is the isolate $19 \mathrm{RB}$ (isolate from Leucaena leucacephala plant) has a higher influence to the growth of A. hypogaea $\mathrm{L}$.
\end{abstract}

Keywords: Arachis hypogaea L, biological fertilizer, rhizobacteria

Received: 19 February 2018 Revised: 08 June 2018 Accepted: 20 November 2018

\section{Introduction}

Peanut (Arachis hypogaea L) is a crop having high economic value apart from soybean and mung beans. The demand for peanuts keeps increasing by a year. Domestic production is not cover the market need, thus import supply was needed. So, the production capacity need to be improved (Eman \& Sumarno, 2014). Boosting the productivity of Arachis hypogaea L plants is conducted by improving the fertilization by using chemical fertilizer as well. However, the high expense of chemical fertilizer encouraged to find an alternative fertilizer that capable providing plant nutrients, such as biofertilizer. Biofertilizer, its low price, capable to maintain soil fertility, improve crop production and protect the environment (Gupta et al., 2015). Rhizobacteria is included as group of biological fertilizers.

Rhizobacteria are capable to live in the soil, within a root nodule and to grow in a symbiotic contact with leguminous or plants. These bacteria have a role in nitrogen fixation, growth hormones production, enzyme siderophores, proteases and other substances production. Rhizobacteria are capable to associate with plant roots such as living in the roots rhizosphere and living independently in the soil. These bacteria belong to a group of plant growth promoting bacteria called PGPR (Plant Growth Promoting Rhizobacteria (Aditya, 2009; Hemahenpagam, 2011), which can be used as a biofertilizer agent due to its ability providing nutrients for plants. Rhizobacteria are also able to supply growth hormone such as auxin, gibberellin and cytokinin that have signifi-

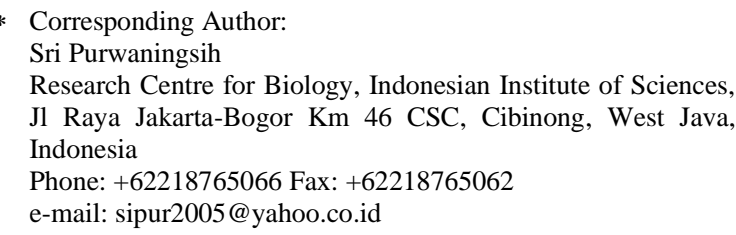

cant effect in the rooting formation system and the siderophores enzymes production as biocontrol. The growth of rooting system would allow, plants, to find the sources of nutrients stimulating a growth and forming a resistance to various diseases (Tisha \& Meenu, 2017; Yousefi \& Barsegar, 2014).

Rhizobacteria are regularly found in the rhizosphere with various number per gram of soil. The factors affecting the population of rhizobacteria are the type of plant and fertilization, soil type, soil $\mathrm{pH}$, carbon source, light intensity, a number of nitrogen-fixing bacteria in the roots, oxygen concentration and an extreme environmental factors (Subha \& Rajesh, 2018). The isolation of rhizobacteria increased the availability of nutrients especially nitrogen (Sadam et al., 2018). The presence of rhizobacteria raised the production of corn and reduced the use of artificial fertilizers about 15-30\% (Damir, 2011). Gomare (2013) stated that the administration of rhizobacteria increased the dry weight of shoot and roots. Rhizobacteria can be applied to agricultural soil as biofertilizer due to the activity of nitrogen fixation and growth hormones production that provide nutrients for plants (Himanshu et al., 2018).

To investigate the existence of Rhizobacteria, the data collection and rhizobacteria isolation had been conducted. This research was expected to obtain a pure culture having the ability in nitrogen fixation, producing growth hormone and siderophores. Thus, effective isolate which able to increase the growth plants could be developed as a biofertilizer improving soil fertility.

\section{Methods \\ Materials}

Composite soil samples were collected randomly at the depth of $0-15 \mathrm{~cm}$ at Suro Muncang and Bukit Peninjau villages. The media used for rhizobacterial isolation was YEMA (Yeast Extract Mannitol Agar) media consist- 
ing of $0,5 \mathrm{~g} \mathrm{~K}_{2} \mathrm{HPO}_{4}, 0,2 \mathrm{~g} \mathrm{MgSO}_{4} 7 \mathrm{H}_{2} \mathrm{O}, 0,1 \mathrm{~g} \mathrm{NaCl}, 3 \mathrm{~g}$ $\mathrm{CaCO}_{3}, 10 \mathrm{~g}$ Mannitol, $3 \mathrm{~g}$ Yeast extract, $20 \mathrm{~g}$ Agar, 1000 mL Aquadest, pH 6.8 (Vincent, 1982).

\section{Isolation, Purification and Characterization of Rhizobacteria}

The isolation was perfomed by serial dillution. $1 \mathrm{~g}$ of soil samples transferred onto $9 \mathrm{~mL}$ of physiological saline solution $(0.85 \% \mathrm{NaCl})$ in a reaction tube then shaken by vortex mixer until $10^{-1}-10^{-5}$. $0.1 \mathrm{~mL}$ solution was poured into a media and incubated at room temperature. The colonies formed were observed and counted daily, using plate count method (Somasegaran \& Hoben, 1994). The isolates obtained was transferred to a slanted media, then purified to obtain a pure isolate. An isolate was transferred onto $5 \mathrm{~mL}$ aquadest and mixed with a vortex. $0.1 \mathrm{~mL}$ was poured in petri dish containing YEMA media, spread evenly with a spatula and incubated at room temperature.

\section{Nitrogen Fixation Test}

The pure isolates were inoculated on a NFB semi solid media (Nitrogen Free Brom Thymol Blue) (Dobereiner, 1991), consisting of $5 \mathrm{~g}$ Malic Acid, $4 \mathrm{~g} \mathrm{KOH}, 0,5 \mathrm{~g}$ $\mathrm{K}_{2} \mathrm{HPO}_{4}, 0,5 \mathrm{~g} \mathrm{FeSO}_{4} 7 \mathrm{H}_{2} \mathrm{O}, 0.01 \mathrm{~g} \mathrm{MnSO}_{4} \mathrm{H}_{2} \mathrm{O}, 0.01 \mathrm{~g}$ $\mathrm{MgSO}_{4} 7 \mathrm{H}_{2} \mathrm{O}, \quad 0.1 \mathrm{~g} \mathrm{NaCl}, 0.02 \mathrm{~g} \mathrm{CaCl}_{2}, 0.002 \mathrm{~g}$ $\mathrm{Na}_{2} \mathrm{MoO}_{4} 2 \mathrm{H}_{2} \mathrm{O}, 4 \mathrm{~mL}$ 1.64\% Fe-EDTA, $4 \mathrm{~g} \mathrm{KOH}, 1 \mathrm{~mL}$ Vit solution, $2 \mathrm{~mL}$ microelement, $2 \mathrm{~mL}$ BTB $(0.5 \%$ alcoholic sol.), $22 \mathrm{~g}$ Agar and $1000 \mathrm{~mL}$ ddH2O. Bacterial isolates were grown in the reaction tube containing semi solid NFB media, and incubated at room temperature for 2-7 days. Nitrogen fixation was indicated by formation of a white ring on the surface of the media.

\section{Indole Acetic Acid (IAA) Fixation Test}

IAA production was analysed qualitatively using TSB (Trypton Soya Broth) media, consisting of $10 \mathrm{~g}$ Peptone, $2.5 \mathrm{~g} \mathrm{NaCl}, 22 \mathrm{~g}$ Agar, $1000 \mathrm{~mL}$ Aquadest. Bacterial isolates were inoculated at the center of the petri dish consisting TSB media, and incubated at room temperature for $2-5$ days. $1 \mathrm{~mL}$ Salkowsky solution $(1 \mathrm{~mL} 0.5 \mathrm{M}$ $\mathrm{FeCl}_{3}+50 \mathrm{~mL} 50 \% \mathrm{HClO}_{4}$ ) dropped onto growing bacterial colonies and incubated in a dark place approximately 1-3 h. IAA production was indicated by a formation pink color (Schroder, 2003).

\section{Siderophores Production Analysis}

The production of siderophores was conducted qualitatively by using selective media, Chrome Sulfate Azurol, framework of CAS Agar, consisting of blue dye $(0.06 \mathrm{~g}$ Chome Azurol in $50 \mathrm{~mL} \mathrm{ddH} 20$ ), $0.0027 \mathrm{~g} \mathrm{FeCl}_{3} 6 \mathrm{H}_{2} \mathrm{O}$ (in $10 \mathrm{mM} \mathrm{HCl}$ ), $0.073 \mathrm{~g}$ HDTMA (in $40 \mathrm{~mL} \mathrm{dd \textrm {H } _ { 2 }}$ ), Gu-

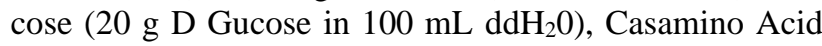
(5 g Casamino Acid in $45 \mathrm{~mL} \mathrm{ddH}_{2} \mathrm{O}+1.35 \mathrm{~g} \mathrm{Hy}-$ droxyquinoline in $45 \mathrm{~mL}$ Chlorofom), MM9 media (5 g $\mathrm{KH}_{2} \mathrm{PO}_{4}, 25 \mathrm{~g} \mathrm{NaCl}, 50 \mathrm{~g} \mathrm{NH}_{4} \mathrm{Cl}$ in $500 \mathrm{~mL} \mathrm{ddH}_{2} 0$ ). CAS

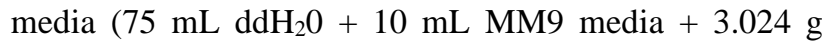
PIPES + $1.5 \mathrm{~g}$ Bactoagar) in autoclave) $+3 \mathrm{~mL}$ Casamino $+1 \mathrm{~mL}$ Glucose $+10 \mathrm{~mL}$ Blue Dye). Bacterial isolates were inoculated onto petri dish containing CAS agar media, then incubated at room temperature for 7 days. The production of siderophores was indicated by the formation of a clear zone around the bacterial colony (Schwyn \& Neilands, 1978).

\section{Rhizobacterial Effectivity Test}

The potential isolates obtained were tested for their effectiveness on Arachis hypogaea L var. Zebra plant growth. The research was conducted in the greenhouse of Microbiology, Research Center for Biology, Indonesian Institute of Science by using sterile sand media, in 0.5 gallon plastic pots. The seeds were planted on a total 1.5 $\mathrm{kg}$ of sterile sand as growing media. Sterile sand mixed with paraffin and benzole (sterile) as high as $2 \mathrm{~cm}$ set as the seed cover. Rhizobacterial isolates used as inoculant were: $1 \mathrm{RB}, 2 \mathrm{RB}, 8 \mathrm{RB}, 9 \mathrm{RB}, 10 \mathrm{RB}, 11 \mathrm{RB}, 16 \mathrm{RB}, 17$ RB, 19 RB, 20 RB, 21 RB. Control plants treated without inoculation and $\mathrm{N}$ fertilizer $\left(\mathrm{K}_{1}\right)$, and without inoculation and supplemeted with $\mathrm{N}$ fertilizer equivalent to $100 \mathrm{~kg} / \mathrm{ha}$ $\left(\mathrm{K}_{2}\right)$. The research design was conducted by Completely Randomized Design with 3 replications per treatment.

Plants were harvested after 45 days planted. The parameters observed were included plant height, number of leaves, shoot dry weight, roots, nodule, total nodule and total dry weight of plant. Watering (nutrient solution without bounded $\mathrm{N}$ ) was conducted everyday to maintain moisture content (24\%) (Saono et al., 1976). The ability of rhizobacterial isolate to form symbiosis contact was determined by Brockwell et al. (1965) as followed

\section{Sc: $\quad(\mathrm{I}-\mathrm{U}) /(\mathrm{N}-\mathrm{U})$}

Sc: Symbiotic capacity

I : average of shoot dry weight of inoculated plant

$\mathrm{U}$ : average of plant dry weight without inoculation and $\mathrm{N}\left(\mathrm{K}_{1}\right)$

$\mathrm{N}$ : average of plant dry weight without inoculation, added with $\mathrm{N}\left(\mathrm{K}_{2}\right)$.

Sc scores were grouped into 4 categories: $\mathrm{E}$ (very effective) if $\mathrm{Sc}>0.67$, c (effective) if $0.33<\mathrm{Sc}<$ 0.67 , e- (less effective) if $\mathrm{Sc}<0.33$ and I (not effective) if Sc $<0$. In addition to Sc, the effectivity test could be performed by comparing the total dry weight of the tested plants to the dry weight of the control plant which was added with $\mathrm{N}\left(\mathrm{K}_{2}\right)$ fertilizer, stated in percentage (Date in Vincent, 1982)

\section{Results}

The numbers of rhizobacterial population were varied in each plant root. Soil samples collecting from Suro Muncang village, Ujan Mas sub-district, Kapahiang district, Bengkulu province were 15 samples. The population of rhizobacterial varied from 14-56 x $10^{5} \mathrm{CFU} / \mathrm{g}$ of soil. The highest number was found in the roots of Avocado (Persian Americana Mill) plants (Tab. 1). Soil samples collecting from Bukit Peninjauan village, Sukaraja subdistrict, Seluma district, Bengkulu province were 10 samples. The number of Rhizobacterial population varied from 13-42 x $10^{5} \mathrm{CFU} / \mathrm{g}$ of soil. The highest number was obtained from root system of rice plant soil (Oryza sativa) (Tab. 2). The number of rhizobacterial isolate showing the ability of nitrogen fixation, IAA production, and siderophores production were 11 isolates (Tab. 3).

The potential isolates were assessed to Arachis hypogaea L observing plant growth (Fig. 1). The results indicated 
that 11 rhizobacterial isolates were capable to form root nodules, which in turn improving plant growth (Figs. 2, 3 and 4). The analysis of symbiotic contact showed that all the rhizobacterial isolates were incredibly effective, therefore the isolates promoted plant growth (Tab. 4). An effectivity percentage of $19 \mathrm{RB}$ isolate was the highest (Tab. 5).

Table 1. Rhizobacterial population in soil samples collecting from Suro Muncang village, Ujan Mas sub-district, Kapahiang district, Bengkulu province

\begin{tabular}{|c|c|c|c|}
\hline Sample code & Root system & $\begin{array}{l}\text { Population of rhizobacteria } \\
(\text { CFUx10 }) / g \text { of soil }\end{array}$ & Number of isolates \\
\hline $1 \mathrm{RB}$ & Corn (Zea mays) & 51 & 3 \\
\hline $2 \mathrm{RB}$ & Banana (Musa paradisiaca) & 49 & 3 \\
\hline $3 \mathrm{RB}$ & Cassava (Manihot utilissima) & 37 & 3 \\
\hline $4 \mathrm{RB}$ & Avocado (Persia americana Mill) & 56 & 3 \\
\hline $5 \mathrm{RB}$ & Orange (Citrus sp.) & 32 & 3 \\
\hline $6 \mathrm{RB}$ & Ambarella (Spondias sp.) & 15 & 3 \\
\hline $7 \mathrm{RB}$ & Pepper (Piper nigrum) & 43 & 3 \\
\hline $8 \mathrm{RB}$ & Melinjo (Gnetum gnemon) & 19 & 3 \\
\hline $9 \mathrm{RB}$ & Gamal / Quick stick (Glyciridia sp.) & 16 & 3 \\
\hline $10 \mathrm{RB}$ & Green Beans (Vigna sinensis) & 26 & 3 \\
\hline $11 \mathrm{RB}$ & Coffee (Coffea sp.) & 21 & 3 \\
\hline $12 \mathrm{RB}$ & Papaya (Carica papaya) & 34 & 3 \\
\hline $13 \mathrm{RB}$ & Dadap/ Coral tree (Erythrina sp.) & 27 & 3 \\
\hline $14 \mathrm{RB}$ & Rice (Oryza sativa) & 14 & 3 \\
\hline $15 \mathrm{RB}$ & Protected forest from Saba Penanjung & 14 & 3 \\
\hline
\end{tabular}

Table 2. Rhizobacterial population in soil samples collecting from Bukit Peninjauan village, Sukaraja sub-district, Seluma district, Bengkulu

\begin{tabular}{|c|c|c|c|}
\hline Sample code & Root system & $\begin{array}{l}\text { Population of Rhizobacteria } \\
\left(\text { CFU X } 10^{5}\right) / g \text { of soil }\end{array}$ & $\begin{array}{l}\text { Number of } \\
\text { isolates }\end{array}$ \\
\hline $16 \mathrm{RB}$ & Rice (Oryza sativa) & 42 & 3 \\
\hline $17 \mathrm{RB}$ & Corn (Zea mays) & 13 & 3 \\
\hline $18 \mathrm{RB}$ & Watermelon (Citrulus lanatus) & 35 & 3 \\
\hline $19 \mathrm{RB}$ & White Lead Tree (Leucaena leucocephala) & 18 & 3 \\
\hline $20 \mathrm{RB}$ & Banana (Musa paradisiaca) & 22 & 3 \\
\hline $21 \mathrm{RB}$ & Without plant & 26 & 3 \\
\hline $22 \mathrm{RB}$ & Oil palm (Elais guinensis) & 33 & 3 \\
\hline $23 \mathrm{RB}$ & Sweet Potato (Ipomea batatas) & 19 & 3 \\
\hline $24 \mathrm{RB}$ & Rubber Plant (Hevea brasilensis) & 36 & 3 \\
\hline $25 \mathrm{RB}$ & Cassava (Manihot utilissima) & 26 & 3 \\
\hline
\end{tabular}

Table 3. The rhizobacterial isolate showing the ability of nitrogen fixation, IAA production, and siderophores production ion collecting from Suro Muncang village, Ujan Mas sub-district, Kapahiang district, Bengkulu

\begin{tabular}{ccccc}
\hline No & Isolate code & N-Fixation test & IAA production & Siderophores production \\
\hline 1 & $1 \mathrm{RB}$ & + & + & + \\
2 & $2 \mathrm{RB}$ & + & + & + \\
3 & $8 \mathrm{RB}$ & + & + & + \\
4 & $9 \mathrm{RB}$ & + & + & + \\
5 & $10 \mathrm{RB}$ & + & + & + \\
6 & $11 \mathrm{RB}$ & + & + & + \\
7 & $16 \mathrm{RB}$ & + & - & + \\
8 & $17 \mathrm{RB}$ & + & + & + \\
9 & $19 \mathrm{RB}$ & + & + \\
10 & $20 \mathrm{RB}$ & + & + \\
11 & $21 \mathrm{RB}$ & & + \\
\hline
\end{tabular}

Table 4. Nodule formation, number of nodules (nn), Symbiotic capacity (Sc) and effectivity percentage (PK) of rhizobacterial isolates inoculated to Arachis hypogaea $\mathrm{L}$ plants (45 days old)

\begin{tabular}{ccccc}
\hline Isolates code & Nodule formation & nn & & Sc \\
\cline { 3 - 4 } & & & Real value & Relative value \\
\hline $1 \mathrm{RB}$ & + & $88.33 \mathrm{bc}$ & 0.50 \\
$2 \mathrm{RB}$ & + & $111.67 \mathrm{de}$ & $\mathrm{e}$ & 1.27 \\
$8 \mathrm{RB}$ & + & $116.00 \mathrm{de}$ & $\mathrm{E}$ & 0.31 \\
$9 \mathrm{RB}$ & + & $118.33 \mathrm{de}$ & $\mathrm{e}$ & 1.02 \\
$10 \mathrm{RB}$ & + & $75.33 \mathrm{~b}$ & 0.93 \\
$11 \mathrm{RB}$ & + & $105.67 \mathrm{de}$ & $\mathrm{E}$ & 1.05 \\
$16 \mathrm{RB}$ & + & $112.67 \mathrm{de}$ & $\mathrm{E}$ & 1.20 \\
$17 \mathrm{RB}$ & + & $76.66 \mathrm{~b}$ & $\mathrm{E}$ & 101.46 \\
\end{tabular}




\begin{tabular}{ccccc}
\hline $19 \mathrm{RB}$ & + & $110.33 \mathrm{de}$ & $\mathrm{E}$ & 1.63 \\
$20 \mathrm{RB}$ & + & $96.66 \mathrm{~cd}$ & 1.02 & 118.40 \\
$21 \mathrm{RB}$ & + & $113.33 \mathrm{de}$ & $\mathrm{E}$ & 102.76 \\
$\mathrm{~K}_{1}$ & - & $0.00 \mathrm{a}$ & 0.90 & 0 \\
$\mathrm{~K}_{2}$ & - & $0.00 \mathrm{a}$ & 0 & 0 \\
\hline
\end{tabular}

Note: number followed by the same letter in every column showed no significant difference in Duncan Test at the $5 \%$ significance level

Table 5. The highest average and percentage of plant growth on plants inoculated with rhizobacterial isolates

\begin{tabular}{ccc}
\hline Parameters & Isolate code (the highest) $(\mathbf{g})$ & Growth Rise (\%) \\
\hline dwc (45 days old) & $19 \mathrm{RB}(6.94)$ & 57.14 \\
$\mathrm{r}($ 45 days old) & $19 \mathrm{RB}(0.36)$ & 71.42 \\
rn (45 days old) & $21 \mathrm{RB}(0.3644)$ & 0 \\
tp (45 days old) & $19 \mathrm{RB}(7.27)$ & 18.40 \\
$\mathrm{nn}(45$ days old $)$ & $9 \mathrm{RB}(118.33)$ & 0 \\
\hline
\end{tabular}

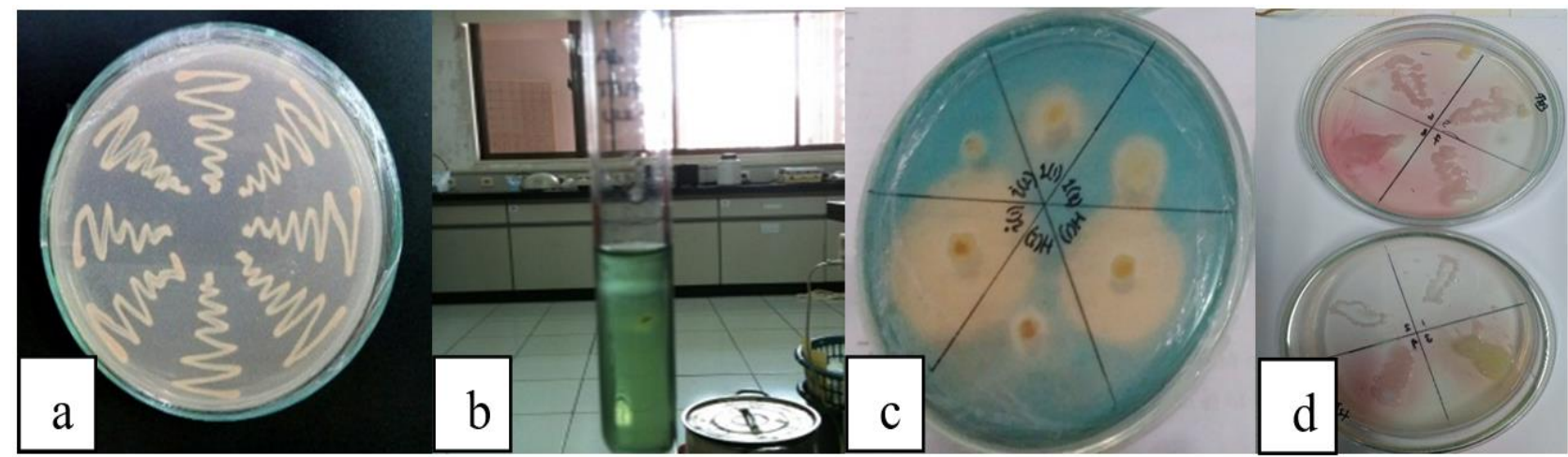

Figure 1. (a) The pure isolate in YEMA media, (b) Nitrogen Fixation, (c) Siderophore production, (d) IAA production.

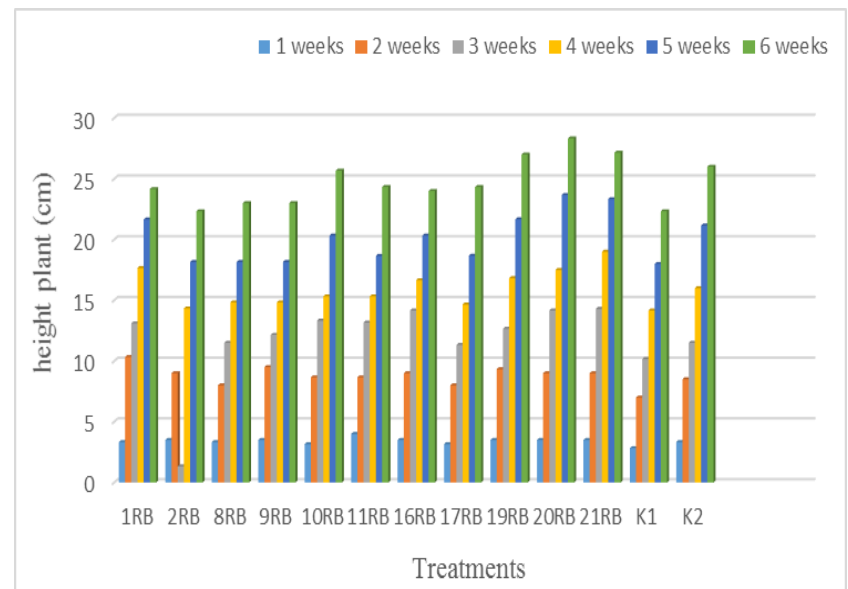

Figure 2. The average of plant height Arachis hypogaea L plants inoculated with rhizobacterial isolates $(\mathrm{cm})$.

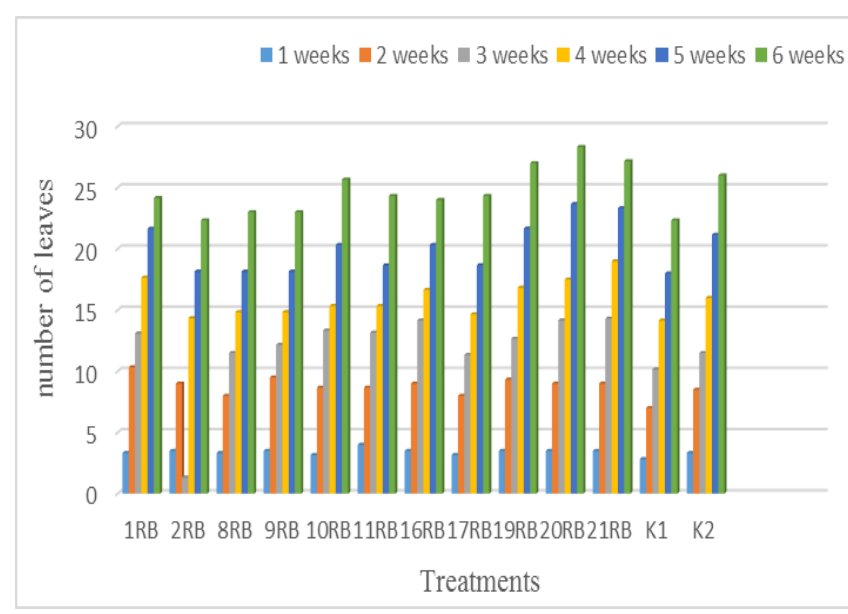

Figure 3. The average of leaves number Arachis hypogaea L plants inoculated with Rhizobacterial isolates. घwc $\|\mathrm{r}\| \mathrm{rn}$ itp

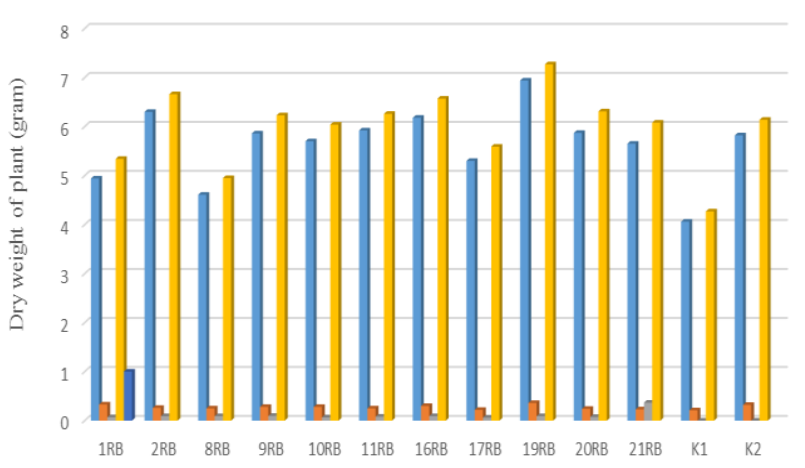

Treatments

Figure 4. The average of dry weight of canopy (dwc), roots (r), root nodules (rn) and total plants (tp) of Arachis hypogaea L plants inoculated with Rhizobacterial isolates.

\section{Discussion}

The results of the study showing that the number of rhizobacterial population found in soil samples suround plants rooting system was higher than in soil samples without plants. It was due to the association of rhizobacteria with plants which bacteria consumed organic material or exudate released by plants through rooting as nutrients. Consequently, the numbers of rhizobacteria in the root area were plentiful. Rhizosphere is part of the soil with the highest metabolic activity defined as a small volume of soil directly influenced by root growth and 
metabolism (Naz, 2012). Root exudates caused plants and microbes interacting and stimulating each other, while affecting the growth and activity of microbes in the rhizosphere, rhizoplan and its surroundings (Abera, 2015).

In addition, the rooting areas of plants were occupied by beneficial organisms utilizing organic substrates or plant exudates as energy and nutrients sources. Some microbes play an important role for soil health and indicators determining soil quality (Jamal, 2010; Hajnal et al., 2012). Kizilkaya (2009) stated that rhizosphere was the area where biological and chemical activity of the soil took place. Both activity were influenced by releasing substances from plant roots continuously which play as nutrients source for soil microbe. Soil microorganism increased the availability of plants nutrients in the process of organic materials decomposition. Rhizobacteria as plant growth promoting agents produces various growth hormones and organic acids needed in the development of root hairs to improve plant growth (Mark et al., 2016; Defez et al., 2016). It can be concluded that there was a mutually beneficial symbiotic relationship between the plant and the inoculated of rhizobacteria.

There were 75 Rhizobacterial isolates obtained (Fig. 1a). The isolates grown in semi-solid NFB media formed white ring beneath in the media surface (Fig. 1b). It suggested that the isolates had nitrogen-fixing ability. It implied that the isolates were capable to provide available nitrogen for plants to grow and to develop and to increase soil fertility (Pajeres \& Bohhanan, 2016). Isolates grown in TSB media formed a pink color (Fig. 1d), it indicated that 31 isolates capable to produce IAA hormone. Bacterial isolate that produce high IAA hormones may control physiological processes include cell expansion and division. In addition, it also able to form more lateral roots and root hair. Thus, the roots were able to extract more nutrients from the soil which eventually increase the growth and yield of the plant (Chaiharn \& Lumyong, 2011).

Isolates grown in siderophores media formed a clear zone. It indicated that 24 isolates were able to produce siderophores (Fig. 1c). Siderophores play an important role in the host plant resistance. Siderophores were specific iron-bearing compounds produced by microbes that supplied available $\mathrm{Fe}^{3+}$ for plants and micronutrients in the rhizosphere. Therefore, those nutrients were not available for the development of pathogenic microbes (Sivasakthivalen \& Stella, 2012).

Among 75 isolates obtained, there 11 isolates showed a high activity (Tab. 3) inoculated against on Arachis hypogaea $\mathrm{L}$ plant growth. This phenomena showed that 11 rhizobacterial isolates able to increase growth. It indicated that these isolates may form effective symbiotic contact with Arachis hypogaea L plants. It was characterized by better vegetative growth compared to non-inoculated control plants and without $\mathrm{N}$ fertilizer addition $\left(\mathrm{K}_{1}\right)$. According to Pushp et al. (2011) an effective symbiotic ability is known when inoculated rhizobacterial isolates formed root nodules. It showed that the nitrogen fixation works well which in turn improves plant growth. Plant growth was observed based on required parameter including on the highest plant height and number of leaves which found in the plant inoculated with isolate 20
$\mathrm{RB}$, on the highest dry weight of shoots, root and plant total value which found in the plant inoculated with isolate $19 \mathrm{RB}$, and on the measurement of dry weight of the highest rated nodule which found in the plant inoculated with isolate $21 \mathrm{RB}$.

Analysis on symbiotic capacity showed that the inoculated rhizobacterial isolates were very effective which resulted eventually in growth improvement. Parameswari et al. (2015) stated that excellent plant growth indicated the success of microbial inoculation. Well growth showed that microbial inoculated was able to form symbiotic contact with plants to increase growth.

Effectivity percentage was greatly affected by the characteristic of each isolate inoculated and suitability to the host plants. Effective and beneficial symbiosis contact will be established once the isolates fit and suitable for the host plants. Dasnadi et al. (2011) stated that there were differences in compatibility of symbiotic contact between isolates and host plants. Furthermore, it was also affected by physiological and environmental factors.

The observation of overall parameters showed that the isolate $19 \mathrm{RB}$ had the highest plant growth in almost all observed parameters. It indicated that the isolate was effective and capable to form symbiosis contact with Arachis hypogaea L plants, and this isolate can be developed as a biological organic fertilizer agent, especially for Arachis hypogaea $\mathrm{L}$ plants.

The results of the study showed that the number of rhizobacterial population in both villages vary extensively. The number of bacteria ranged from $13-51 \times 10^{5}$ $\mathrm{CFU} / \mathrm{g}$ of soil. The highest bacterial population were found in the root system of corn crops (Zea mays). There were a total of 75 isolates obtained, 75 isolates had nitrogen fixation ability, 31 isolates were able to produce IAA hormone and 24 isolates were able to produce siderophores. Isolate number $19 \mathrm{RB}$ presented the highest plants growth on Arachis hypogaea L. Such isolates can be developed as biological fertilizer agents, especially Arachis hypogaea $\mathrm{L}$ plants.

\section{Acknowledgment}

The authors would like to thank the technicians and staffs at the Agricultural Microbiology Laboratory, Microbiology Division, Research Center for Biology, who had been very helpful in this research, and financed by LIPI thematic DIPA Project 2014.

\section{References}

Abera, T., Semu, E., Debele, T., Wegary, D., \& Kim, H. (2015). Determination Soil Rhizobium Populations, Intrinsic Antibiotic Resistance, Nodulation and Seed Yield of Faba Bean and Soybean in Western Ethiopia. World Journal of Agricultural Science 11(5), 311-324. doi: 10.5829/ idosi.wjas.2015.11.5.1869.

Aditya, B., Ghosh, A., Cattopadhyay, D. (2009). Co-Inoculation Effects on Nitrogen Fixing and Phosphate Solubilising Microorganism on Teak (Tectona grandis) and Indian Redwood (Chukrasia tubularis). E-journal of Biology Sciecne. Retrivied from www.indianforester.co.in/ index.php/indianforester/.../92290.

Browckwell, J., Hely, F. W., \& Neal-Smith, C. A. (1965). Some symbiotic as effective field nodulation of Lobus hipidus. Australian Journal Experimental Agriculture. Anim. Husba 6(3), 365-370.

Chaiharn, M., \& Lumyong, S. (2011). Screening and Optimization of Indole-3-Acetic Acid Production and Phosphate Solubilization 
from Rhizobacteria Aimed at Improving Plant Growth. Current Microbiology. 62, 173-181. doi: 10.1007/s00284-010-9674-6.

Damir, O., Mladen, P., Božidar, S., \& Srnan, O. (2011). Cultivation of the bacterium Azotobacter chroococcum for preparation of biofertilizers. African Journal of Biotechnology 10(16), 3104 3111.

Dashadi, M., Khosravi, H., Moezzi, A., Nadian, H., Heidari, M., \& Radjabi, R. (2011). Co-Inoculation of Rhizobium and Azotobacter on growth indices of faba bean under water stress in the green housecondition. Advanced Studies in Biology, 3, 373-385.

Defez, R., Esposito, R., Angelini, C., \& Bianco, C. (2016). Overproduction of Indole-3-Acetic Acid in Free-Living Rhizobia Induces Transcriptional Changes Resembling Those Occurring in Nodule Bacteroids. Moecularl Plant Microbe Interact. 29(6), 484495. doi: 10.1094/MPMI-01-16-0010

Dobereiner, J. (1991). The genera of Azospirillum and Herbaspirillum in the Prokaryotes. $2^{\text {nd }}$ ed.vol 3.Spinger-Verlag,NewYork. pp. 2236

Eman, P., \& Sumarno. (2014). Peningkatan Produktivitas kacang Tanah melalui penerapan Komponen Tehnologi Kunci. Iptek tanaman Pangan. 9(2), 97-107.

Gupta, G., Parihar, S. S., Ahirwar, N. K., Snehi, S. K., \& Singh, V. (2015). Plant Growth Promoting Rhizobacteria (PGPR): Current and future Prospects for development of sustainable agriculture. Microbial \&Biochemical Technology, 7(2), 96-102.

Gomare, KS., Mese, M., Shetkar, Y. (2013). Isolation of Azotobacter and Cost Effective Production of Biofertilizer. Indian Journal of Applied Research. Issues, (3), 55-56

Hajnal-Jafari, T., Latkovic, D., Duric, S., Mrkovacki, N., \& Najdenovska, O. (2012). The use of Azotobacter in organic maize production. Research Journal of Agricultural Science 44(2), 28-32.

Hemahenpagam, N., \& Selvaraj, T. (2011). Effect of arbuskuler mycorrhizal (AM) fungus plant growth promoting microorganisms (PGPR'S) on medical plant Solanum viarum seedling. J. Environ. Biol. 32, 579-583.

Himanshu, D., Rao, D. L.N., Seemab, A., Gayatri, M., \& Shahi, D. K. (2018). Isolation of Novel Acid Soil tolerant Isolates of Rhizobium from "Pigeon Pea" and Proteomic Characterization by Utilizing MALDI-TOF/TOF and "Peptide Mass Fingerprinting" Approachto Identify Genes Associated with Acid-soil Tolerance. Environment and Ecology Research, 6(1), 45-59. doi: 10.13189/eer.2018.060104

Jamal, A., Moon, Y. S., \& Abdin, M. Z. (2010). Enzyme activity assessment of Peanut (Arachis hypogaea L.) under slow-release sulphur fertilization. Australian Journal of Crop science, 4(3), $169-174$

Kizilkaya, R. (2009). Nitrogen Fixation Capacity of Azotobacter spp. Strains Isolated from Soils in Different Ecosystems and Relationship Between Them and The Microbiological Properties of Soils. Journal of Environmental Biology, 30, 73-82.

Mark, A., Balendres., David, S., Nichols., Robert, S., Tegg., Calum, R., \& Wilson. (2016). Metabolomes of Potato Root Exudates: Compounds That Stimulate Resting Spore Germination of the Soil-Borne Pathogen Spongospora subterranean. Journal of Agriculturan and Food Chemistry, 64 (40), 7466-7474. doi: 10.1021/acs.jafc. 6b03904.
Naz, I., Bano, A., Rehman, B., Pervaiz, S., Iqbal, M., Sarwar, A., \& Yasmin, F. (2012). Potential of Azotobacter vinelandii Khsr1 as bio-inoculant. African Journal of Biotechnology, 11(45), 10368-10372.

Pajares, S., \& Bohannan, B. J. M. (2016). Ecology of Nitrogen fixing, nitrifying, and denitrifying microorganisms in tropical forest soils. Frontiers in Microbiology 7(1045), 1-20. doi: 10.3389/fmicb.2016.01045.

Parameswari, K., Hemalatha, M., \& Kishori, B. (2015). Isolation, screening, and molecular characterization of plant growth promoting rhizobacteria isolates of Azotobacter and Trichoderma and their beneficial activities. Journal of Natural Science Biology and Medicine, 6(2), 360-363. doi: 10.4103/09769668.160006

Pushp, S., Virender, S., \& Kandola, S. S. (2011). Response of Groundnut (Arachis hypogaea L.) to Rhizobium Inoculation. Libyan Agriculture Research Centre. Journal International. 2(3), 101 104

Sadam, D. V., Satyanarayana, M. S. R., Krishna., \& Pindi, P. K. (2018). Identification of Upregulated Nitrogen Fixing Bacteria for Arachis hypogaea by Exploring Natural Combination:A Physical, Biochemical, and In silico Approach. Journal of Pure and Applied Microbiology. 12(1), 73-83.

Saon,o S., Karsono, H, \& Suseno, D. (1976). Studies on the effect of different rhizobial strains on Phaseolus lunatus in sand culture. Annales Bogorience 6(2), 143-154.

Schroder, P., \& Hartmann, A. (2003). New developmants in Rhizospher Research. Journal of Soil \& Sedimens 3(4), 227.

Schwyn., \& Neilands. (1978). Universal Assay Chemical for the Detection and Determination of Siderophores. Analytical Biochemistry.160(1), 47-56.

Sivasakthivalen, P., \& Stella D. (2012). Studies on Phytohormon Producing Potensial of Agriculturally Beneficial Microbial (ABM) Isolates from Different Rhizospers Soils of Sunflower in Tamil Nadu. International journal of Pharmaceuticaland Biological Archives 3(5), 1150-1156.

Subha, D., \& Rajesh, G. (2018). Siderophore Production by Rhizobia Isolated from Cluster Bean [Cyamopsis tetragonoloba (L.) Taub.] Growing in Semi-Arid Regions of Haryana, India. International.Journal of Current .Microbiology and.Applied Science. 7(3), 3187-3191.

Somasegaran, P., \& Hoben, H. J. (1994). Handbook for Rhizobia: Methods in Legume Rhizobium Technology, SpringerVerlag, New York. pp. 58-64.

Tisha P., \& Meenu S. (2017). Biosynthesis of phytohormones from novel rhizobacterial isolates and their in vitro plant growthpromoting efficacy. Plant-Microorganism Interactions. pp. 480-487.

Vincent, J. M. (1982). A manual of the Practical study of the root Nodule Bacteria. International Biological Programme. London. Handbook. No15. 164 p.

Yousefi, A., \& Barzegar, A. (2014). Effect of Azotobacter and Pseudomonas bacteria inoculation on wheat yield under field condition. International Journal of Agriculture and. Crop Science, 7(9), 616-619. 